\title{
Modeling and Thermodynamic Values of Complex Equilibrium of Cobalt(II) with Diethylenetriaminepentaacetic Acid in Aqueous Solution
}

\author{
Ghusoon Faidhi Hameed ${ }^{1}$, Fawzi Yahya Wadday ${ }^{2 *}$, and Nahla Shakir Salman ${ }^{1}$ \\ ${ }^{1}$ Department of Chemistry, Faculty of Education, Al-Qadisiyah University, Al-Qadisiyah, Iraq \\ ${ }^{2}$ Department of Chemistry, Faculty of Science, Kufa University, Al-Najaf, Iraq
}

*Corresponding author:

tel: $+964-7811443061$

email:Fawzi.almuwashi@uokufa.edu.iq

Received: August 31, 2020

Accepted: October 26, 2020

DOI: $10.22146 / \mathrm{ijc} .59169$

\begin{abstract}
The paper reports the study of the complex formation of cobalt (II) with diethylenetriaminepentaacetic acid (DTPA, $\mathrm{H}_{5} \mathrm{~L}$ ) based on spectrophotometric (SF) and potentiometric data $(p H)$. Complexes of different compositions were found, and equilibrium constants, as well as the stability constants of these complexes, were determined. Accumulation of complexes in proportion is calculated based on the acidity of the medium. The experimental data have been carried out by using mathematical models to assess the solution's possible existence with a wide spectrum of complex particles and to point out those which are quite sufficient to copy the experimental data. In addition, thermodynamic parameters $\left(\Delta G^{\circ}, \Delta H^{\circ}\right.$, and $\left.\Delta S^{\circ}\right)$ for the studying complexes were calculated according to the values of stability constant $\left(K_{S T}\right)$ at $25^{\circ} \mathrm{C}$ obtained from the temperature dependence of stability constant by using van't Hoff equation.
\end{abstract}

Keywords: cobalt; stability constants; spectrophotometer; potentiometer

\section{- INTRODUCTION}

It is known that DTPA, being an octadentate pentabasic ligand, forms stable water-soluble complexes with many metal cations including cobalt(II). These complexes are widely used in various fields of science, technology, agriculture, and medicine [1-2]. It is known that all animal and plant organisms need trace elements. The latter should be introduced into living organisms in a biologically active form, easily transported and absorbed. The use of inorganic metal salts for these purposes is ineffective. The most promising substances in this regard are biologically active complexes, especially, DTPA. The introduction of metal complexes into the soil contributes not only to an increase in micronutrient fertilizers but also to their mobility. Some metal complexes with DTPA contribute to the growth and productivity of crops and increase the yield and quality of potato tubers. Iron complexonate with DTPA is a useful tool in the fight against plant chlorosis. Some of the biochemicalcomplexes are used in animal husbandry and the food industry [3-5]. In medicine, metal complexes can play the role of antidotes, regulators of mineral metabolism, as anticancer and antiviral, antimicrobial, and diagnostic drugs [6-8]. It should be noted that the cumulative properties of complexions and their complexes are very weakly expressed. Accumulation coefficients indicate a low potential risk of developing chronic poisoning with these drugs.

Cobalt, on the other hand, is a biologically active metal. Excessive "technogenic" intake of this metal in the body has a toxic effect on metabolism and has a carcinogenic effect on the cell [9]. The widespread use of cobalt and DTPA salts necessitates a detailed study of equilibrium in the Co(II)-DTPA system. In the previous studies, cobalt and DTPA complexes have been widely used in agriculture and medicine, the researchers used spectrophotometer measurements and did not use voltage measurements data and programs while the thermodynamic values of the complexes were not calculated [3], thus it is necessary to be studied in more detail. In our current study, the equilibrium constants were measured based on spectrophotometer (SF) and voltage data $(\mathrm{pH})$, and the stability constants of these complexes are determined by using mathematical 
modeling and also calculated the thermodynamic parameters $\left(\Delta \mathrm{G}^{\circ}, \Delta \mathrm{H}^{\circ}\right.$ and $\left.\Delta \mathrm{S}^{\circ}\right)$ for complexes.

The thermodynamic parameters represented by standard free energy change where values of stability constants can be expressed in terms of free energy or standard Gibbs $\left(\Delta \mathrm{G}^{\circ}\right)$ [10-12], as in Eq. (1):

$\Delta \mathrm{G}^{\circ}=\mathrm{RT} \ln \mathrm{K}_{\mathrm{eq}}$

Standard enthalpy change $\Delta \mathrm{H}^{\circ}$ of equilibrium constant can be determined from Eq. (2) as follows [12-14]:

$\ln \mathrm{K}_{\mathrm{eq}}=-\Delta \mathrm{H}^{\circ} / \mathrm{RT}+$ constant

The standard entropy change $\Delta S^{\circ}$ for each compound was calculated by using the following Eq. (3) [12-16]:

$\Delta \mathrm{G}^{\circ}=\Delta \mathrm{H}^{\circ}-\mathrm{T} \Delta \mathrm{S}^{\circ}$

\section{- EXPERIMENTAL SECTION}

\section{Materials}

The chemical reagents used in this research were diethylenetriaminepentaacetic (DTPA, $\mathrm{C}_{14} \mathrm{H}_{23} \mathrm{~N}_{3} \mathrm{O}_{10}$ ), potassium hydroxide $(\mathrm{KOH})$, sodium hydroxide $(\mathrm{NaOH})$, sodium nitrate $\left(\mathrm{NaNO}_{3}\right)$, hydrochloric acid $(\mathrm{HCl}$ fuming $37 \%)$, cobaltous sulfate heptahydrate $\left(\mathrm{CoSO}_{4} \cdot 7 \mathrm{H}_{2} \mathrm{O}\right)$ were purchased from Sigma-Aldrich, Merck (Germany and British). All reagents were used without further purification.

\section{Instrumentation}

Instruments used in this research were Spectrophotometer SF-2000 No. 0311112000 (Russia), pH Meter PW 9421 Philips (England), Electric Balance + 0.0001g L420 B Sartorius (Germany), and Distillate Water Lab Tech (Korea).

\section{Procedure}

The complex solution was prepared by dissolving $3.929 \mathrm{~g}$ from a reagent grade DTPA in $250 \mathrm{~mL}$ distilled water. The solution that concentration $0.04 \mathrm{M}$ of DTPA was clarified by $\mathrm{pH}$-metric titration with a standard solution of $0.1 \mathrm{M} \mathrm{KOH}$. A $0.04 \mathrm{M}$ cobalt(II) solution was prepared by dissolved $2.808 \mathrm{~g}$ of $\mathrm{CoSO}_{4} \cdot 7 \mathrm{H}_{2} \mathrm{O}$ salt in $250 \mathrm{~mL}$ of distilled water. Then $\mathrm{Co}^{2+}$ ions were standardized by redox metric titration with a DTPA solution. The necessary acidity of the medium was supported by $0.1 \mathrm{M}$ for both $\mathrm{HCl}$ and $\mathrm{NaOH}$ solutions. A constant ionic strength $(\mathrm{I}=0.1 \mathrm{M})$ was created with $\mathrm{NaNO}_{3}$ solution.
The optical density of the solutions was measured on an SF-2000 spectrophotometer using quartz cuvettes with an absorbing layer length of $1 \mathrm{~cm}$. The concentration of hydrogen ions was measured on an I$160 \mathrm{M}$ ion meter (ES-10601/7 working electrode and ESr-10101 reference electrode). The main absolute error of $\mathrm{pH}$ measurement was \pm 0.01 . The redox potential value was measured using a platinum electrode EPL-02. All measurements were carried out at a temperature of $20 \pm 2{ }^{\circ} \mathrm{C}$. The calculation of equilibrium parameters in the Co(II)-DTPA system was carried out using the computer programs HypSpec (spectrophotometer) and Hyperquad 2008 (potentiometer) [17-18].

\section{- RESULTS AND DISCUSSION}

To study the complexation process in the $\mathrm{Co}(\mathrm{II})-$ DTPA system, the absorption spectra of solutions were collected for various values of the acidity of the medium (Fig. 1). A comparison of the obtained spectra with the spectra of $\mathrm{Co}(\mathrm{II})$ solution shows that $\mathrm{Co}(\mathrm{II})$ complexes with DTPA were already formed in a strongly acidic medium ( $\mathrm{pH}=0.5-6.88)$. In DTPA's presence, the absorption band of hydrated $\mathrm{Co}(\mathrm{II})$ ions at $350 \mathrm{~nm}$ disappears while the optical density increases in the region of $450-550 \mathrm{~nm}$ with a maximum at $506 \mathrm{~nm}$.

To calculate the composition and stability of the resulting Co(II) complexes with DTPA, the HypSpec program was used. This program allows us to analyze the experimental dependence of the optical density on $\mathrm{pH}$ simultaneously for different wavelengths of 300-750 nm in accordance with the selected complexation model. For complexes of the molar composition Co(II):DTPA $=1: 1, \mathrm{Co}\left(\mathrm{H}_{\mathrm{i}} \mathrm{L}\right)^{\mathrm{i}-3}(\mathrm{i}=0-5)$ and $\mathrm{Co}(\mathrm{OH})_{\mathrm{j}} \mathrm{L}^{(3+\mathrm{j})-}(\mathrm{j}=0-1)$, and also hydroxo complexes $\mathrm{Co}(\mathrm{OH}) \mathrm{k}_{2}-\mathrm{k}(\mathrm{k}=1-3)$, we performed calculations for various compositional models, including complexness. In the calculations, we used fixed values of the DTPA dissociation constants, previously determined by us by $\mathrm{pH}$ metric titration as below. The total hydrolysis constants of Co (II) were taken from the literature as $\left(\mathrm{K}_{\mathrm{i}}=\left[\mathrm{Co}(\mathrm{OH})_{\mathrm{i}}^{3-\mathrm{i}}\right]\left[\mathrm{H}^{+}\right]^{\mathrm{i}} /\left[\mathrm{Co}^{2+}\right]\right.$ : $\mathrm{pK}_{1 \mathrm{~W}}=9.7 ; \mathrm{pK}_{2 \mathrm{~W}}=9.1 ; \mathrm{pK}_{3 \mathrm{~W}}=12.7\left(\mathrm{I}=0.1, \mathrm{t}=25^{\circ} \mathrm{C}\right)$ [19-20]. The HypSpec program allows modeling in automatic mode by comparing the experimental and 

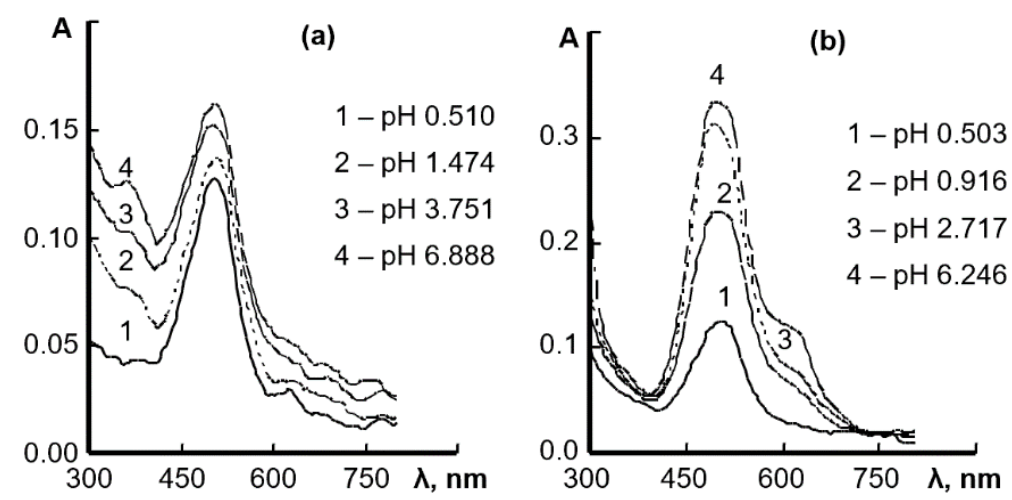

Fig 1. Absorption spectra of (a) Co (II) solution, and (b) Co(II)-DTPA complex. $\mathrm{C}_{\mathrm{Co}(\mathrm{II})}=1.6 \times 10^{-2} \mathrm{~mol} / \mathrm{L}, \mathrm{C}_{\mathrm{DTPA}}=$ $2.4 \cdot \times 10^{-2} \mathrm{~mol} / \mathrm{L}$

calculated spectra represented by the sum of the spectra of all absorbing particles.

For Co(II)-DTPA system in the studied range of medium acidity $(0<\mathrm{pH}<7)$, the minimum standard deviation corresponds to a model that includes the following particles: $\mathrm{Co}^{2+}, \mathrm{CoH}_{2} \mathrm{~L}^{-}, \mathrm{CoHL}^{2-}, \mathrm{CoL}^{3-}$. The calculated values of the total stability constants are presented in Table 1. Fig. 2 shows a comparison of the experimental and calculated optical density values (at $506 \mathrm{~nm}$ ) for the established complexation model, which shows their good agreement. At $\mathrm{pH}>11$, hydrolysis proceeds in the system, and turbidity appears in the solution.

Spectrophotometer method established complex compounds of cobalt with DTPA at different ionic strengths values; $\left[\mathrm{CoH}_{4} \mathrm{~L}\right]^{+}\left(\lg \beta\|=\| 30.18, \mathrm{I}=0.1,25{ }^{\circ} \mathrm{C}\right)$
[21], $[\mathrm{CoL}]^{3-} \lg \beta\|=\| 19.72,[\mathrm{CoHL}]^{2-} \lg \beta\|=\| 22.47,(\mathrm{I}=0$, $\left.20^{\circ} \mathrm{C}\right)[22]$.

The diagram of the molar distribution of complexes in the Co(II)-DTPA system (Fig. 2(b)) allows us to compare the observed spectral changes with the regions of existence of individual complexes characterized by the spectra shown in Fig. 3.

Table 1. Composition and stability constants of complexes in the Co(II)-DTPA system

\begin{tabular}{ccc}
\hline Complex & $\lg \beta$ & Terms, Method \\
\hline $\mathrm{CoH}_{2} \mathrm{~L}^{-}$ & $26.55( \pm 0.01) \mathrm{SF}$ & \\
& $25.38( \pm 0.04) \mathrm{pH}$ & \\
$\mathrm{CoHL}^{2-}$ & $22.87( \pm 0.05) \mathrm{SF}$ & $\mathrm{I}=0.1\left(\mathrm{NaNO}_{3}\right), 21^{\circ} \mathrm{C}$ \\
& $22.67( \pm 0.02) \mathrm{pH}$ & $\mathrm{SF}, \mathrm{pH}$ \\
$\mathrm{CoL}^{3-}$ & $18.39( \pm 0.10) \mathrm{SF}$ & \\
& $17.79( \pm 0.03) \mathrm{pH}$ & \\
\hline
\end{tabular}
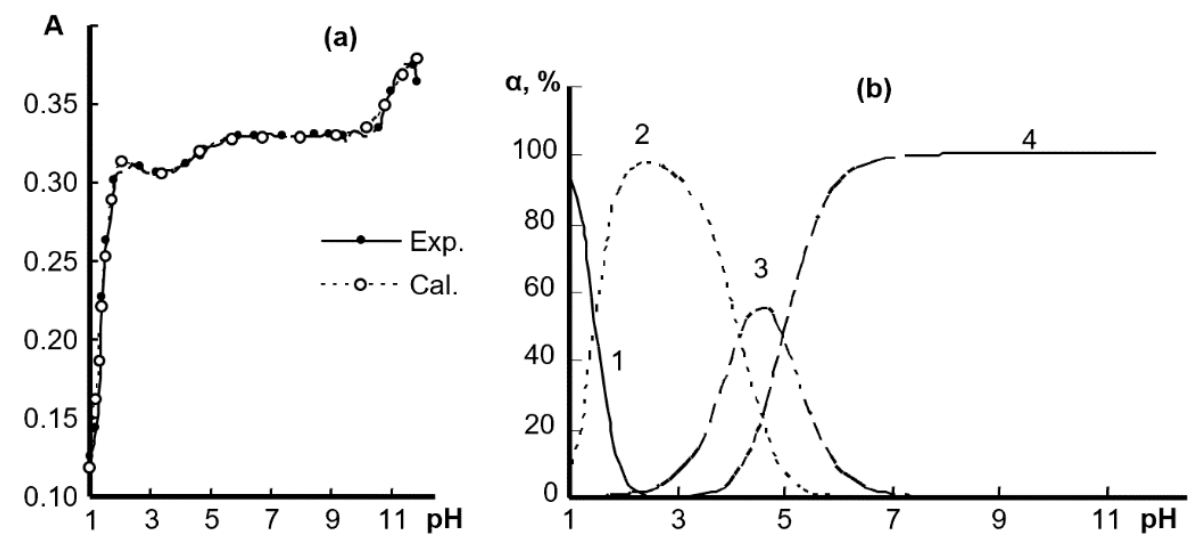

Fig 2. (a) Experimental and calculated dependences of optical density $(\lambda=506 \mathrm{~nm})$ and diagram of the molar distribution of complexness. (b) Versus pH for the system $\mathrm{Co}(\mathrm{II})-\mathrm{DTPA}$, where $\mathrm{Co}$ (II) (1), $\mathrm{CoH}_{2} \mathrm{~L}^{-}$(2), $\mathrm{CoHL}^{2-}$ (3), $\mathrm{CoL}^{3-}(4), \mathrm{C}_{\mathrm{Co}(\mathrm{II})}=1.6 \times 10^{-2} \mathrm{~mol} / \mathrm{L}, \mathrm{C}_{\text {DTPA }}=2.4 \times 10^{-2} \mathrm{~mol} / \mathrm{L}$ 
Three buffer regions are observed on the $\mathrm{pH}$ metric DTPA titration curve $(0<\mathrm{a}<3 ; 3<\mathrm{a}<4 ; \mathrm{a}>4 ; \mathrm{a}=$ degree of titration) and one distinct jump at $\mathrm{a}=3$ (Fig. 4). In the presence of $\mathrm{Co}$ (II) cations, a decrease in the $\mathrm{pH}$ of solutions associated with complexation is observed. To calculate the equilibrium in the Co(II)-DTPA system, the Hyperquad 2008 program was used, designed to process various potentiometer data, including $\mathrm{pH}$-metric ones. Initially, the DTPA dissociation constants were calculated from the DTPA titration curve $\left(\mathrm{pK}_{1}=2.2 ; \mathrm{pK}_{2}=2.9 ; \mathrm{pK}_{3}\right.$ $\left.=4.4 ; \mathrm{pK}_{4}=8.7 ; \mathrm{pK}_{5}=10.04\right)$, which were then used as fixed values when calculating the composition and stability of the resulting Co(II) complexes as depicted in Table 1.

In the alkali medium, the oxidation of cobalt in the main layers occurs much more slowly, the final product of which is $\mathrm{CoO}(\mathrm{OH})$ or $\mathrm{Co}_{2} \mathrm{O}_{3} \cdot \mathrm{H}_{2} \mathrm{O}$ Fig. 4 [23]. In the absence of oxidation, that is, without access to air, the blue form ( $\alpha$-form) turns into pink ( $\beta$-form). The unstable $\alpha$ form is distinguished, which is associated with its organization of two-dimensional particles, which can be considered as the initial structure of a hexagonal layered lattice corresponding to a stable monomorphic $\beta$-form. Particles of the $\alpha$-form are characterized by smaller sizes and a lower degree of perfection of the crystal lattice compared to particles of the $\beta$-form.

The experimental and calculated titration curves exhibited a good agreement with the entire $\mathrm{pH}$ range and the complexes' corresponding distribution diagram as shown in Fig 5. Compared with spectrophotometer technique, the $\mathrm{pH}$-metric method does not identify the presence of the $\mathrm{CoH}_{3} \mathrm{~L}$ complex in the system since its existence region lies at lower $\mathrm{pH}$ values than those studied. A potentiometer study shows that, at $\mathrm{pH}>7$, the $\mathrm{CoL}^{3-}$ complex is formed in solution in the middle region as shown in Fig. 5. The stability constants of complexes established by both methods are reasonably close as given in Table 1.

Thus, the work results show that, at Co (II) concentrations in the range of $2 \times 10^{-4}-2 \times 10^{-3} \mathrm{~mol} / \mathrm{L}$ with the excess of DTPA, only soluble complexes are formed in the solution. The formation of insoluble polynuclear complexes under these conditions is not observed. DTPA is characterized by the formation of protonated complexes with $\mathrm{Co}(\mathrm{II})$ already in a strongly acidic medium. In the $\mathrm{pH}$ range close to neutral in solution, there is an average $\mathrm{CoL}^{-}$complexions, whose stability $(\log \beta=17-18)$ is only slightly inferior to the stability of the Co(II)-EDTA ${ }^{2-}$ complex $(\log \beta=16.31)$ [24]. The results obtained are consistent with some published data (see Table 1). The high stability and wide $\mathrm{pH}$ range of the existence of $\mathrm{Co}(\mathrm{II})$ complexes with DTPA are a positive factor when using DTPA for various practical purposes [3,17]. The strong binding of $\mathrm{Co}(\mathrm{II})$ cations

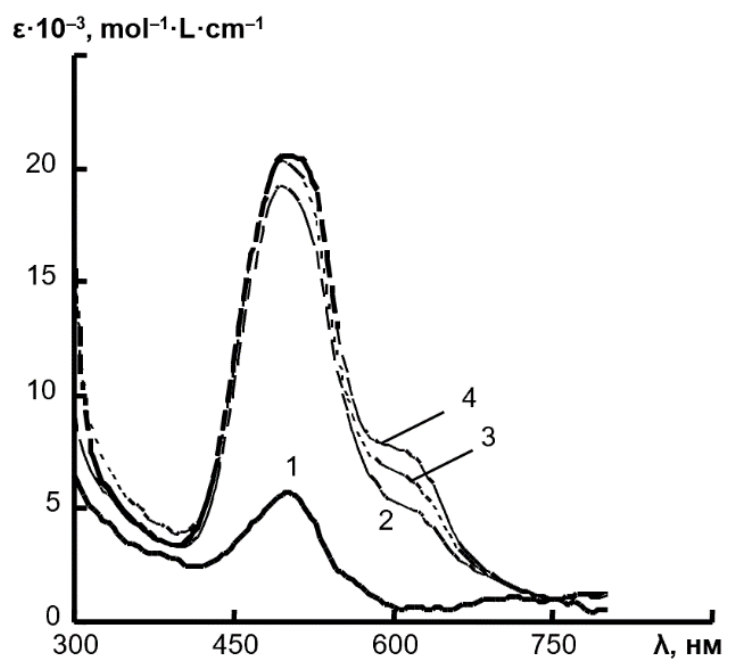

Fig 3. The calculated absorption spectra of the complexes $\mathrm{Co}(\mathrm{II})$ with DTPA for $\mathrm{Co}(\mathrm{II})(1), \mathrm{CoH}_{2} \mathrm{~L}^{-}$(2), $\mathrm{CoHL}^{2-}$ (3) and $\mathrm{CoL}^{3-}$ (4), $\mathrm{C}_{\mathrm{Co} \text { (II) }}=\mathrm{C}_{\text {DTPA }}=1.62 \times$ $10^{-3} \mathrm{~mol} / \mathrm{L}$

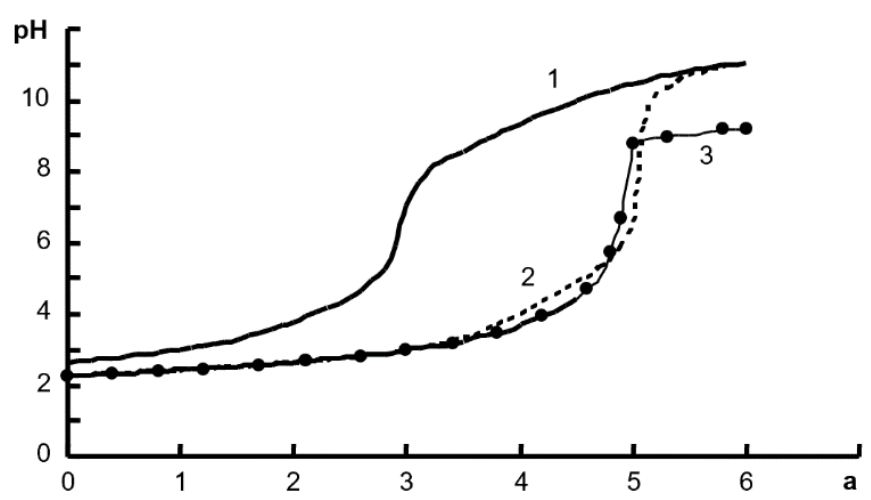

Fig 4. Curves of $\mathrm{pH}$-metric titration of DTPA and its complex with $\mathrm{Co}$ (II) for DTPA (1), $\mathrm{C}_{\mathrm{DTPA}}=2 \times 10^{-3}$ $\mathrm{mol} / \mathrm{L}$ and mixtures $\mathrm{Co}(\mathrm{II})-\mathrm{DTPA}$ with the ratio 1:2 (2) and $1: 1(3)$ 

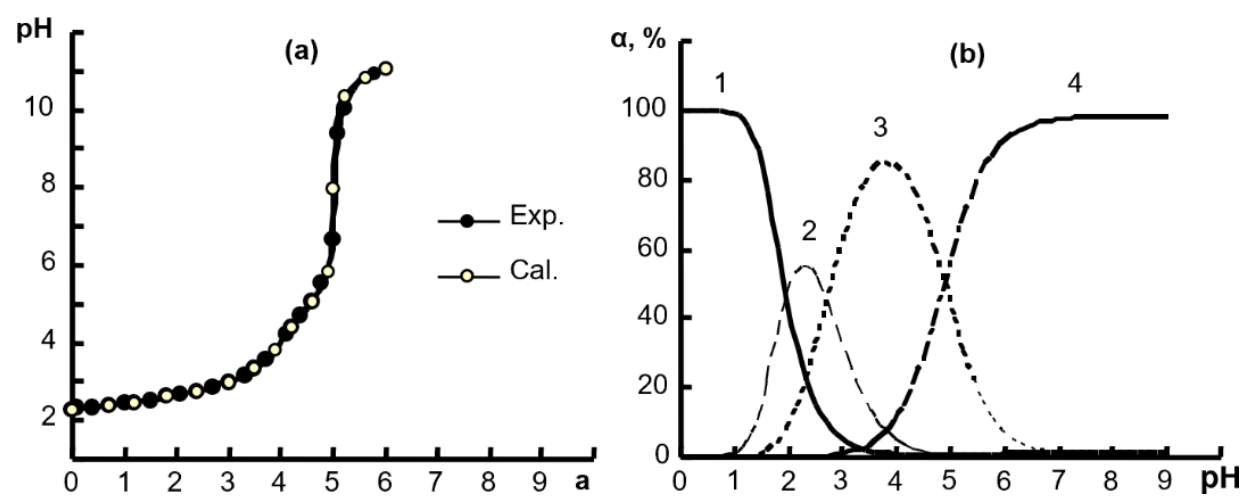

Fig 5. (a) Experimental and calculated pH-metric titrated curves, (b) The molar distribution diagram of complexes in the $\mathrm{Co}(\mathrm{II})-\mathrm{DTPA}$ system as a function of pH For Co (II) (1), $\mathrm{CoH}_{2} \mathrm{~L}^{-}(2), \mathrm{CoHL}^{2-}$ (3) and $\mathrm{CoL}^{3-}(4), \mathrm{C}_{\mathrm{Co}(\mathrm{II})}=\mathrm{C}_{\mathrm{DTPA}}=$ $2 \times 10^{-3} \mathrm{~mol} / \mathrm{L}$

under the action of DTPA allows the use of DTPA as a stabilizer of peroxides in household detergents and bleaches. Despite the lack of data on various forms of DTPA in the environment, it can be assumed that a significant proportion of DTPA in natural waters will be in the form of complexes with $\mathrm{Co}(\mathrm{II})$ and other metals. This photolysis leads to the degradation of DTPA in nature.

From the dependence of $\mathrm{K}_{\text {eq }}$ on temperature (T), the thermodynamic function $\left(\Delta \mathrm{G}^{\circ}, \Delta \mathrm{H}^{\circ}, \Delta \mathrm{S}^{\circ}\right)$ were calculated. The values were summarized in Table 2 at $25^{\circ} \mathrm{C}$. The $\Delta \mathrm{G}^{\circ}$ values were obtained from the reaction of complexes indicating a spontaneous reaction. The positive values of $\Delta \mathrm{H}^{\circ}$ (endothermic reaction) were obtained for complexes by using van't Hoff equation. Meanwhile, the $\Delta S^{\circ}$ values indicate that complexes are brought into being [25-27].

The positive value of $\Delta \mathrm{H}^{\circ}$ is the indicative of endothermic processes, and the formation of these complexes is favored under high temperature. Meanwhile, the negative values of $\Delta \mathrm{G}^{\circ}$ indicate the spontaneous process in each case. On the other hand, the positive values of $\Delta S^{\circ}$ indicate some randomness degree during the formation presses.

\section{- CONCLUSION}

Co(II) complexes have been identified by absorption spectroscopy, $\mathrm{pH}$-meter, and computerassisted mathematical modeling in the Co(II)-DTPA system. Complexation begins in strongly acidic media and occurs in the range of $\Delta \mathrm{pH} 0.5-6.2$ for a 1:1 system. On the other hand, in an alkaline medium in solutions of Co(II) salts, hydrolysis processes are enhanced. In this case, a blue precipitate first forms with increasing $\mathrm{pH}$, while the blue precipitate gradually turns to be purple and finally in pink color.

Table 2. The values of a standard thermodynamic functions $\left(\Delta \mathrm{G}^{\circ}, \Delta \mathrm{H}^{\circ}, \Delta \mathrm{S}^{\circ}\right)$ of equilibrium constants for $\mathrm{CoH}_{2} \mathrm{~L}^{-}$, $\mathrm{CoHL}^{2-}$ and $\mathrm{CoL}^{3-}$ complexes in $25^{\circ} \mathrm{C}$

\begin{tabular}{ccccc}
\hline Complex & $\operatorname{lgK} \mathrm{K}_{\mathrm{eq}}$ & $\Delta \mathrm{G}^{\circ} \mathrm{kJ} \mathrm{mol}^{-1}$ & $\Delta \mathrm{H}^{\circ} \mathrm{kJ} \mathrm{mol}^{-1}$ & $\Delta \mathrm{S}^{\circ} \mathrm{J} \mathrm{mol}^{-1} \mathrm{~K}^{-1}$ \\
\hline $\mathrm{CoH}_{2} \mathrm{~L}^{-}$ & $7.37( \pm 0.02) \mathrm{SF}$ & -4.948 & 16.606 & 39.120 \\
& $6.208( \pm 0.03) \mathrm{pH}$ & -4.523 & 15.180 & 35.761 \\
& & & & \\
$\mathrm{CoHL}^{2-}$ & $12.29( \pm 0.04) \mathrm{SF}$ & -6.215 & 20.858 & 49.137 \\
& $12.09( \pm 0.02) \mathrm{pH}$ & -6.175 & 20.721 & 48.812 \\
& & & & \\
$\mathrm{CoL}^{3-}$ & $18.39( \pm 0.10) \mathrm{SF}$ & -7.214 & 24.208 & 57.026 \\
& $17.79( \pm 0.03) \mathrm{pH}$ & -7.132 & 23.932 & 56.375 \\
\hline
\end{tabular}




\section{- ACKNOWLEDGMENTS}

The authors would like to thank the Department of Chemistry, College of Education for Pure Science, University of Al-Qadisiyah, and College of Science, Kufa University in Iraq for funding this work.

\section{- REFERENCES}

[1] Dyatlova, N.M., Temkina, V.Y., and Popov, K.I., 1988, Kompleksony i kompleksonaty metallov (Complexones and Compexonates of Metals), Khimiya, Moscow.

[2] Martak, F., Cahyani, N.W.D., Nugraheni, Z.V., and Utomo, W.P., 2016, Properties and toxicity of cobalt(II) complex with 2,4,5-triphenyl-1Himidazole ligand, Indones. J. Chem., 16 (3), 260-267.

[3] Rawat, K.S., Kumar, R., and Singh, S.K., 2019, Topographical distribution of cobalt in different agro-climatic zones of Jharkhand state, India, Geol. Ecol. Landsc., 3 (1), 14-21.

[4] Hall, L.H., Spijkerman, J.J., and Lambert, J.L., 1968, Preparation and coordination studies of the complex acid, dihydrogen diethylene-triaminepentaacetato ferrate(III) dihydrate, and several of its metal(I) salts, J. Am. Chem. Soc., 90 (8), 2044-2048.

[5] Sugiyarto, K.H., Kusumawardani, C., and Wulandari, K.E., 2018, Synthesis and structural analysis of powder complex of tris(bipyridine) cobalt(II) trifluoromethanesulfonate octahydrate, Indones. J. Chem., 18 (4), 696-701.

[6] El-Sherif, A.A., Shoukry, M.M., Abd Elkarim, A.T., and Barakat, M.H., 2014, Protonation equilibria of biologically active ligands in mixed aqueous organic solvents, Bioinorg. Chem. Appl., 2014, 626719.

[7] Sucipto, T.H., Churrotin, S., Setyawati, H., Mulyatno, K.C., Amarullah, I.H., Ueda, S., Kotaki, T., Sumarsih, S., Wardhani, P., Bendryman, S.S., Aryati, A., Soegijanto, S., and Kameoka, M., 2017, Inhibitory activity of cobalt(II)-morin complex against the replication of dengue virus type 2, IJTID, 6 (6), 141144.

[8] Rakhmanin, Y.A., 2016, Actualization of methodological problems of regimentation of chemical pollutions on the environment, Gig. Sanit., 95 (8), 701-707.

[9] Cui, P., Yin, Q., Gong, J., Wang, Y., Hao, H., Xie, C., Bao, Y., Zhang, M., Hou, B., and Wang, J., 2013, Thermodynamic analysis and correlation of solubility of candesartan cilexetil in aqueous solvent mixtures, Fluid Phase Equilib., 337, 354-362.

[10] Wang, Z., Long, Z.W., Long, C.Y., and Zhang, W., 2015, On the thermodynamic properties of the spinless Duffin-Kemmer-petiau oscillator in noncommutative plane, Adv. High Energy Phys., 2015, 901675.

[11] Kumar, A., Rout, S., Ghosh, M., Singhal, R.K., and Ravi, P.M., 2013, Thermodynamic parameters of U (VI) sorption onto soils in aquatic systems, SpringerPlus, 2 (1), 530.

[12] Batool, F., Akbar, J., Iqbal, S., Noreen, S., and Bukhari, S.N.A., 2018, Study of isothermal, kinetic, and thermodynamic parameters for adsorption of cadmium: An overview of linear and nonlinear approach and error analysis, Bioinorg. Chem. Appl., 2018, 343724.

[13] Hussein, A.A., Karem, L.K.A., and Mohammed, S.S., 2020, Preparation, diagnosis, thermodynamic and biological studies of new complexes derived from heterocyclic ligand, Syst. Rev. Pharm., 11 (5), 445-450.

[14] Nwabanne, J.T., 2012, Kinetics and thermodynamics study of oil extraction from fluted pumpkin seed, IJMSE, 3 (2), 11-15.

[15] Anwer, M., Muqtader, M., Iqbal, M., Ali, R., Almutairy, B.K., Alshetaili, A., Alshahrani, S.M., Aldawsari, M.F., Alalaiwe, A., and Shakeel, F., 2019, Estimating the solubility, solution thermodynamics, and molecular interaction of aliskiren hemifumarate in alkylimidazolium based ionic liquids, Molecules, 24 (15), 2807.

[16] Blokhina, S.V., Sharapova, A.V., Ol'khovich, M.V., Volkova, T.V., Proshin, A.N., and Perlovich G.L., 2017, Thermodynamic aspects of solubility and solvation of bioactive bicyclic derivatives in organic solvents, J. Chem. Eng. Data, 62 (12), 4288-4295. 
[17] Jastrzab, R., Kaczmarek, M.T., Tylkowski, B., and Odani, A., 2018, Computer analysis of potentiometric data of complexes formation in the solution, Phys. Sci. Rev., 3 (3), 140.

[18] Singh, J., Srivastav, A.N., Singh, N., and Singh, A., 2019, "Stability constants of metal complexes in solution" in Stability and Applications of Coordination Compounds, IntechOpen Limited, London, UK, 90183.

[19] Plyasunova, N.V., Zhang, Y., and Muhammed, M., 1998, Critical evaluation of thermodynamics of complex formation of metal ions in aqueous solutions. V. Hydrolysis and hydroxo-complexes of $\mathrm{Co}^{2+}$ at $298.15 \mathrm{~K}$, Hydrometallurgy, 48 (2), 153-169.

[20] Mehdi, S.H., and Budesinsky, B.W., 1974, Protonated metal complexes of diethylenetriaminepentaacetic acid (DTPA), J. Coord. Chem., 3 (4), 287-292.

[21] Jelecevic, A. Horn, D., Eigner, H., Sager, M., Liebhard, P., Moder, K., and Vollprecht, D., 2019, Kinetics of lead release from soils at historic mining and smelting sites, determined by a modified electroultrafiltration, Plant Soil Environ., 65, 298-306.
[22] Remy, G., 1966, A Course of Inorganic Chemistry, Vol. 2, Mir, Moscow.

[23] Kornev, V.I., and Alabdulla, G.F., 2017, Simulation of equilibria of formation of mono-and polynuclear heteroligand cobalt(II) and nickel(II) complexonates in aqueous solutions, Russ. J. Inorg. Chem., 62 (8), 1127-1133.

[24] Krajewska, B., and Brindell, M., 2016, Thermodynamic study of competitive inhibitors' binding to urease, J. Therm. Anal. Calorim., 123 (3), 2427-2439.

[25] Tamiji, Z., Yazdanipour, A., and Niazi, A., 2018, Spectrophotometric and thermodynamic study on the dimerization equilibrium of neutral red in the water and micelle environments by chemometrics methods, Int. J. Exp. Spectrosc. Tech., 3, 15.

[26] Baikusheva-Dimitrova, G., Genieva, S., and Yankova, R., 2017, Synthesis, thermal behavior and thermodynamic data of hafnium selenite tetraaqua complex dihydrate, Int. J. Sci. Eng. Appl. Sci., 2 (3), 137-144. 